TA'DIB: JURNAL PENDIDIKAN ISLAM, 25(2), 2020

Avaliable Online At: http://jurnal.radenfatah.ac.id/index.php/tadib

\title{
Integrating Islamic Values on ESL Classes: Indonesian Teachers' Attitudes Toward Islamic Education Management in South Thailand
}

\author{
Iswan $^{1 *}$, Zaitun ${ }^{1}$ \\ ${ }^{1}$ Universitas Muhammadiyah Jakarta, Jakarta, Indonesia \\ *Corresponding Author Email: iswanfipumj@gmail.com
}

\begin{tabular}{ll}
\hline \multicolumn{1}{c}{ ARTICLE INFO } & \multicolumn{1}{c}{ ABSTRACT } \\
\hline $\begin{array}{l}\text { Article History: } \\
\text { Received : 08-07-2020 }\end{array}$ & This research study was aimed to investigate ESL teachers' \\
Revised: $30-07-2020$ & attitudes toward the policy of integrating Islamic values into \\
Accepted : 16-10-2020 & their teachings. A total number of 32 ESL teachers who were \\
& hired as contract teachers teaching English at several different \\
Keyword: & Islamic schools in South-Thailand participated as respondents. \\
Islamic education; & A set of 5-Likert scale questionnaire to measure the attitude of \\
Islamic education & the respondents was the instrument used by the writers in \\
management; & collecting the data. A quantitative-descriptive method was \\
Islamic values; & applied in this study, in which the data were analyzed \\
Teachers' attitudes toward & statistically before they were descriptively described. The \\
teachings. & findings of the statistical analysis revealed that most of the \\
& teachers have positive attitude (73.63\%) toward this Islamic \\
& school management policy. The percentage was taken from \\
& $47 \%$ responses of the respondents on "Totally Agree" and \\
& 26.63\% on "Agree" options. Thus, it can be concluded that \\
most of ESL teachers who were teaching English at several & Islamic schools in South Thailand had positive attitude towards \\
the policy of integrating Islamic values into their teachings.
\end{tabular}

\section{How to Cite:}

Iswan, I., \& Zaitun, Z. (2020). Integrating Islamic values on ESL classes: Indonesian teachers' attitudes toward Islamic education management in South Thailand. Ta'dib: Jurnal Pendidikan Islam, 25(2), 96-106. 


\section{INTRODUCTION}

In Islamic schools, it is undoubtedly that Islamic education management is applied. As Marimba explained that both physical and spiritual guidance based on the laws of Islam towards the establishment of a majority personality according to the measurements of Islam is referred to Islamic education management (Suryapermana, 2017). Management in educational institutions has a higher determinant among other aspects since it gives impacts to the success of students' learning to develop their ability, characters and civilization (Wibowo \& Utomo, 2018), and in the context of Islamic education management, the process of teaching and learning is managed to build religious attitudes and behaviors of the students. Thus, the ability of the teachers, including English teachers, as the actors of the schools' management should be prepared in such a way so that the lessons can be delivered effectively.

As Moslems belong to minority group of society in the Southern part of Thailand, around 600 Islamic schools also implement Islamic education management under the rules of the government. In relation to this, there are plethora of research studies discuss educational management in various aspects at several Islamic schools in South Thailand (Awang, 2016; Brooks, 2014; Kaewsom, 2017; Yukhong, Phuwanatwichit, Mangkhang, \& Sarobol, 2019). Besides, studies about teachers and or educators related to school management have also been conducted by several scholars.

Nitjarunkul et al. (2014) identified barriers which faced by teachers of the schools in five Southern provinces of Thailand in regards to the reformation of education and disagreement of the violence as well as the characteristics of leaderships that appeared in this context. There were 21 teachers of primary schools in Pattani, Yala, Narathiwat, Songkhla and Satun provinces involved in this study. The findings of their study showed that curriculum management, students' competency in reading, the overburden of work and the limitation of budgets were matters. Another research was conducted by Zain (2018) who discovered some anxieties and reasons of pre-service teachers while doing their teaching practices in Southern Thailand and also elaborated causes and attempts to get the better of these anxieties. The description of their research results were referred Hart's theory which stated four factors of anxieties in the practice of teaching, i.e. 1) evaluation, 2) student-teacher and professional concern, 3) class control and 4) teaching practice requirement. Among these 4 factors, the most common anxiety faced by these studentteachers was student's mind tension.

However, those previous research have neglected to consider the attitudes of ESL teachers who are required to integrate Islamic values into their teachings as part of Islamic education management. Thus, this paper is aimed to explore the attitudes of ESL teachers to the implementation of Islamic education management from the aspects of integrating Islamic values on their teachings. It seeks to find out the answer of: "what is the attitude of ESL teachers towards the requirement of integrating Islamic values into their teachings?".

\section{LITERATURE REVIEW}

\section{Islamic Education Management in the Context of Islamic Schools in South Thailand}

Good management plays a pivotal role in public institution in order to provide the most effective services to society (Wibowo \& Utomo, 2018). While in the context of Islamic schools in which the schools implement the management policy of integrating Islamic values into all subject 1 teachings, Aree \& Rahman (2016) claim that the "aim of integrated Islamic education may be 2 viewed as a distinct equilibrium between moral 
development, derived from spiritual Islamic 3 education, and personal achievement in life as reflected in the cognitive and affective and 4 psychomotor aspects". As Cahyo et al. (2019) explain that each of the three components 5 that should support the creation of students' akhlak in the following Figure1:

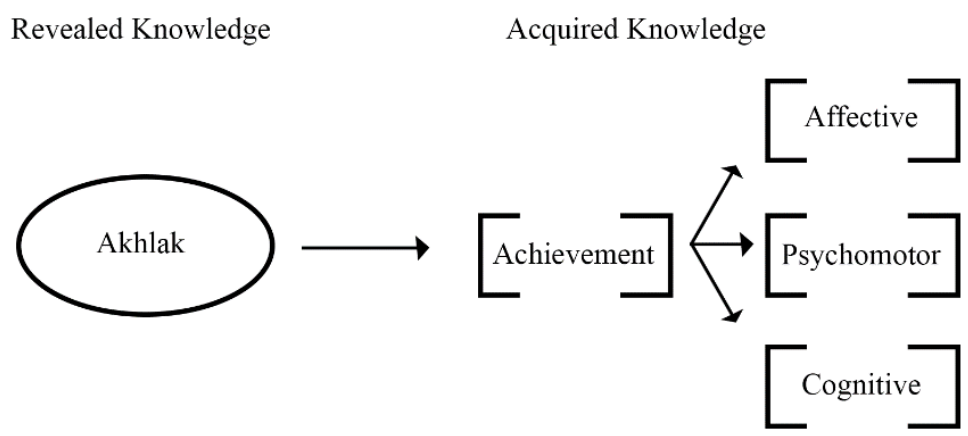

\section{Figure 1. Islamic Concept and Education Objective Concept}

Further, they add that having a wide scope of knowledge, both secular and Islamic, and also projecting a balanced personality will be the goals expected from the graduates of this integrated Islamic education. Based on these references, discussing Islamic education management means that the process of teaching and learning or educating the students should be managed in such a way by the schools so that the goals to implement Islamic values will be achieved.

According to Munastiwi and Marfuah (2019), establishing Islamic values should be performed continuously and followed by examples or models. Planning and implementing the learning of Islamic religion needs to be taught with good models, methods, strategies, approaches and media.

In the Southern-part of Thailand, in which this province is having most Moslems, there are several Islamic schools were established. And it is going without saying that each school has its own Islamic education management and one of the policies is that all teachers of the schools (even non-Islamic education teachers) are required to integrate Islamic values into their teachings.

According to Yukhong et al. (2019), looking back to the history of Islamic education in Southern part of Thailand, the development of educational management has passed several phases and Moslem citizenship there have faced considerable number of challenges such as educational management, courses development, model and teaching method, measurement and evaluation process. They also add that Islamic private schools' curriculums have been modified to meet the challenges of the current globalization. The Moslem citizens should be more educated and have capability to apply their knowledge in their contemporary religious lives or their chosen professions, such as adapting to the changes in the society by using multi languages, advanced technology, analytical thinking skills or media literacy skills.

\section{The Integration of Islamic Values into ESL Teachings}

In this globalization era, it goes without saying that English takes the most important role in the process of education. Thus, in some non-English countries, English is even taught from kindergarten until university level. However, learning a language does not only learn the alphabets, sentence buildings, grammatical patterns, pronunciations, and 
meanings, even more it also learns the social norms of the societies such as people's behavior, attitudes, ways of interactions, belief etc, which is called 'culture'. As Ali et al. (2015) argues that individuals who deal with a language should take culture as an important and integral part of communicating that language. "..... a language is a part of a culture and a culture is a part of a language" (Brown, 1994). Referring to this fact, the ideas of integrating Islamic education into English teaching is primarily aimed to give the learners strong fundamental of Islamic values so that they will be able to understand English culture without neglecting the values of Islam.

According to Madkur and Albantani (2017), it is necessary to integrate Islam in all lessons including foreign language since the preservation of the religious values could be done by Muslim teachers through the classroom activities. The integration itself has been previously explained by them which elaborated 4 implementations of: 1) character values accommodated in the lesson, 2) character values integrated in every activity of learning, 3) character values delivered through the method of teaching, and 4) character education values planted and practiced through everyday life.

Even though the implementation of integrating Islamic values into ESL teaching is not easy, especially for the teachers, Ekowijayanto (2020) gives his best opinions in which teaching Islamic education through English learning will make students, teachers/lecturers, curriculum designers, and textbooks to be creative in order to disseminate Islamic values contextually.

\section{Teachers' Attitudes Toward Teachings}

Teachers' attitudes matter (Dixon, Liew, Daraghmeh, \& Smith, 2016). Their attitudes toward their profession as teacher affect students' aspires of involvement in the teaching process (Maryrose \& Kingsley, 2018). In the English as a second language classroom, Gursoy (2013) claimed that a positive attitude towards English should be possessed by this language teacher hence this positive attitude could be reflected in the atmosphere of the class. Thus, the positive attitudes and motivation of the students can be explored through the application of efficacious methods and techniques coming from the willingness of the teachers to teach the language reflected from his or her positive attitude.

There are several factors influenced teachers' attitudes in English language learning. As Byrnes \& Kiger (1994) proposed three factors that comprise English teachers' attitudes in their classrooms, i.e. language politics, ELL intolerance, and language support (Dixon et al., 2016). Further, they gave the examples which make up the language politics factor such as common societal attitudes about the language that claim, for instances, 'English should be the only one language used by the authorities', and 'every migrant has to use English to be admitted as American'. Intolerance English learning was described by them in items such as, 'The process of English language learning is hurtful to the learning of other students', and 'the students of English language learning frequently used unfair claims of inequity as an apology for not doing right at school'. While for the factor of language support, it could be seen from the ideas such as 'The executives should give extra money to support the programs of English language learning to be better', and 'The needs of English language learning should be fulfilled by well-trained regular-classroom teachers'.

The attitudes of teachers toward certain aspects can be measured through several scales or questionnaires. If a teacher has negative attitudes, then he or she will surrender the profession. Brooks and Sikes (1997) as cited in Maryrose and Kingsley (2018) stated 
that students' academic success, personality, interest, etc. are affected by the intellectual attitudes, emotional reactions, various habits and personality of their teachers.

Sener (2015) previously described that the lives of students can be positively changed through teachers' positive attitudes and productive actions, hence, examining preservice teachers' experiences of education and attitude differences will be useful for these teacher-candidates to illumine things should or should not do in their real future classrooms.

\section{METHOD}

Since the purpose of this research was to measure the attitudes of ESL teachers toward Islamic education management of integrating Islamic values into their teachings, then a quantitative-descriptive method was applied in this study. In addition, a quantitative survey research was applied. Check and Schutt (2012) defined survey research as the information collected from individuals as sample of the research through their responses to a set of questions. A frequency distribution was used to describe the ordinal data of the instrument. The data to measure those teachers' attitudes was calculated statistically before being presented in percentages.

In determining the participants of this study, the writers applied purposive sampling technique in order to select only non-Thailand ESL teachers who were being contracted as English teachers by several Islamic schools in South Thailand. There was a total number of 32 non-Thailand ESL teachers from several Islamic schools in the Southern-part of Thailand participated as the respondents. They were teaching at kindergarten to secondary levels and having 2 to 5 years teaching experiences at those schools.

A set of ordinal 5 Likert-scale was used by the respondents to rate the degree to which they agree or disagree to each of the statement. This questionnaire was modified from the one used by Saygi (2010) in doing her research on music teaching course. There are 25 statements in this questionnaire in which each of them was rated on a 5-to-1 Totally Agree-Totally Disagree response scale. This closed response questionnaire was distributed by the writers to each participant online in Google form. These teachers were required to give their responses to those 25 items based on their teaching experiences. Those 25 statements of the questionnaire can be seen in the following table:

Table 1. Questionnaire of ESL Teachers' Attitudes Toward Islamic Teaching

\begin{tabular}{|c|c|}
\hline No. & Statement \\
\hline 01. & Islamic teaching is not a boring course \\
\hline 02. & Islamic course is one of the courses that I like \\
\hline 03. & Islamic course is one of my favorite courses \\
\hline 04. & I relax when teaching Islamic values in my EFL classes \\
\hline 05 . & $\begin{array}{l}\text { I discovered my Islamic knowledge by means of integrating Islamic education in } \\
\text { my class }\end{array}$ \\
\hline 06. & $\begin{array}{l}\text { I would very much like to participate in the Islamic teaching sessions even } \\
\text { though I have to study hard to deepen my knowledge }\end{array}$ \\
\hline 07. & I feel that I have learned a lot by means of Islamic teaching \\
\hline 08. & $\begin{array}{l}\text { I like integrating Islamic values in my class because the students understand my } \\
\text { explanation }\end{array}$ \\
\hline 09. & Islamic teaching session is a time which makes me happy during the teaching \\
\hline 10. & I have a high motivation for Islamic education teaching \\
\hline 11. & I think I will benefit from Islamic education improve my knowledge about Islam \\
\hline 12. & In teaching Islamic lessons, we are asked to do things that we are not able to do \\
\hline 13. & $\begin{array}{l}\text { My self-confidence has heightened when inserting Islamic teachings in my EFL } \\
\text { class }\end{array}$ \\
\hline 14. & Islamic education teaching is a joyful session \\
\hline
\end{tabular}


15. My interest and sympathy toward Islamic values has increased by means of integrating Islamic education into my EFL classrooms

16. I look forward to implementing any school policy about the integration of Islamic values into my class

17. I voluntarily do any learning about Islamic education in order to prepare for my Islamic sessions in the class

18. I want to learn how to teach Islamic education better

19. I think Islamic education will be beneficial for me in the future

20. Even though I come to the class reluctantly I still enjoy giving the knowledge about Islam to my class

21. I feel sad if the session of delivering Islamic values is limited

22. I shy away from asking questions to the Islamic education teachers at my school

23. I feel tense in delivering Islamic education since I am afraid that the students do not understand my explanation

24. I think that what I have to teach in Islamic education session is very difficult

25. I do not grasp well the lessons about Islamic knowledge that I study before coming to the class

Then, the data were analyzed statistically through the calculation of frequency distribution. Firstly, the writers collected the raw data from entity responses on the questionnaire. Since the data were nominal, they were then being listed into classes in which they each data point fell. Secondly, the raw number of data points in each class was calculated to get the sum of all the absolute frequencies. Thirdly, the sum of this absolute frequency was divided by total number of the sample size $(\mathrm{N}=32)$ which resulted the percentages of the data points in each class. Lastly, the percentages of data points in each class were added to the cumulative frequency calculation and reported in percentages.

\section{FINDINGS}

Based on the responses of the 32 respondents to 25 items in the questionnaire, the frequency distribution was shown in the following table 2 :

Table 2. Frequency Distribution of the Respondents' Responses Toward the Questionnaire

\begin{tabular}{cccccc}
\hline No. & $\mathbf{X i}$ & $\mathbf{f}$ & $\mathbf{X i} \mathbf{2}^{\mathbf{2}}$ & $\mathbf{f X i}$ & $\mathbf{F x}^{\mathbf{2}}$ \\
\hline 1. & TA (5) & 376 & 25 & 1880 & 9400 \\
2. & A (4) & 213 & 16 & 852 & 3408 \\
3. & N (3) & 74 & 9 & 222 & 666 \\
4. & D (2) & 65 & 4 & 126 & 260 \\
5. & TD (1) & 72 & 1 & 60 & 72 \\
& Sum & 800 & & 3140 & 13806 \\
Mean & & & & 3.925 \\
& Median & & & & 4.387 \\
& Modus & & & 4.934 \\
& Variance & & & 370.375 \\
& Standard Deviation & & & 19.245 \\
\hline
\end{tabular}

Looking at the results on the table above, the mean (average response) was 3.925 with a standard deviation (range of response) of 19.245. As the number of the respondents was low $(\mathrm{N}=32)$, and percentage differences were produced, then total number of respondents responding to each statement was presented in percentages to show its significant differences.

Overall, the responses to the statements were mostly 'totally agree' and 'agree'. In which the frequency reached for 'totally agree' was 376 (47\%), while for 'agree' was 213 $(26.63 \%)$. The responses given to the questions as 'neither agree nor disagree' reached 74 
in frequency $(9.25 \%)$, a number of 65 for the frequency of 'disagree' $(8.12 \%)$, and 72 as the frequency number of 'totally disagree' (9\%).

The statements which received two highest responses on the option of 'totally agree' were no. 7 "I feel that I have learned a lot by means of Islamic teaching", (in which 28 of 32 respondents responded to this statement) and the statement no. 18 "I want to learn how to teach Islamic education better" (in which 26 of 32 respondents chose this). Another two statements that shared the highest responses on 'totally agree' were the statement no. 5 "I discovered my Islamic knowledge by means of integrating Islamic education in my class" (which got 25 responses out of 32), and statement no. 22 "I shy away from asking questions to the Islamic education teacher at my school" (which got 21 responses out of 32).

For the option of 'agree', the statements which received 4 highest responses from the respondents were statement no. 2 "Islamic course is one of the courses that I like", and statement no. 20 "Even though I come to the class reluctantly I still enjoy giving the knowledge about Islam to my class" (in which each of the statements got 13 responses out of 32), statement no. 6 "I would very much like to participate in the Islamic teaching sessions even though I have to study hard to deepen my knowledge", and the statement no. 21 "I feel sad if the session of delivering Islamic values is limited" (which received 12 responses out of 32 for each), the statement no. 3 "Islamic course is one of my favorite courses", statement no. 4 "I relax when teaching Islamic knowledge in my class", statement no. 10 "I have a high motivation for Islamic education teaching", statement no. "I think I will benefit from Islamic education which improves my knowledge about Islam", statement no. 13 "My self-confidence has heightened when inserting Islamic teachings in my EFL class", and the statement no. 19 "I think Islamic education will be beneficial for me in the future" (in which each of these statements got 11 responses out of 32). The statement no. 1 "Islamic teaching is not a boring course", and statement no. 15 "My interest and sympathy toward Islamic values has increased by means of integrating Islamic education into my EFL classroom" received 10 responses out of 32 respondents.

The lowest responses gained in the option of 'strongly agree' were on the statement no. 25 "I do not grasp well the lessons about Islamic knowledge that I study before coming to the class", and the statement no. 24 "I think that what I have to teach in Islamic education session is very difficult" (in which each of these items received 2 and 4 responses out of 32 respondents). These two statements also got the least responses in the 'agree' option with the responses from 2 and 4 respondents out of 32.

On the contrary to the option of 'totally agree', the 4 highest options received by 'totally disagree' were statement no. 25 "I do not grasp well the lessons about Islamic knowledge that I study before coming to the class" (got 16 out of 32), statement no. 24 "I think that what I have to teach in Islamic education is very difficult" (got 15 out of 25), statement no. 12 "In teaching Islamic lessons we are asked to do things that we are not able to do" (got 14 out of 32), and statement no. 23 "I feel tense in delivering Islamic education since I am afraid that the students do not understand my explanation" (got 7 out of 32). While for the 'disagree' option, the 4 statements which received the highest 4 responses were statement no. 25 "I do not grasp well the lessons about Islamic knowledge that I study before coming to the class" (got 12 out of 32), statement no. 24 "I think that what I have to teach in Islamic education is very difficult" and statement no. 23 "I feel tense in delivering Islamic education since I am afraid that the students do not understand my explanation" (in which of them received 5 responses). The statements which got 4 responses from 32 respondents were statement no. 2 "Islamic course is one of the courses I 
like", statement no. 3 "Islamic course is one of my favorite courses", statement no. 20 "Even though I come to the class reluctantly, I still enjoy giving the knowledge about Islam to my class", and statement no. 21 "I feel sad if the session of delivering Islamic values is limited".

There was 0 option for several statements both in 'totally disagree' and 'disagree'. A total number of 8 statements got no response from the respondents for 'totally disagree', i.e. statements no. $2,5,8,9,10,13,16$, and 18 . While for 'disagree', the respondents gave no response to 5 statements, i.e. statements no. $5,7,13,14$, and 19.

The option of "Neither Agree nor Disagree' received the first highest response on the statement no. 17 "I voluntarily do any learning about Islamic education in order to prepare for my Islamic sessions in the class" which got 8 answers. The second highest choice received in this option was on the statement no. 14 "Islamic education teaching is not a joyful session" which got 7 responses. While the third and the fourth highest scores in this option were on the statement no. 10 "I have a high motivation for Islamic education teaching" and statement no. 19 "I think Islamic education will be beneficial for me in the future" with 6 responses for each., followed by statement no. 1 "Islamic teaching is not a boring course", statement no. 12 "In teaching Islamic lessons, we are asked to do things that we are not able to do", and statement no. 24 "I think that what I have to teach in Islamic education session is very difficult" (in which each of the statements received 5 responses). There was no respondent who gave their responses to the statements no. 3, 5, 6, $7,18,22$ and 25 to this option.

To sum, total responses of the respondents toward each scale of the questionnaire can be seen in the following figure 2 :

\section{Percentages of Respondents' Attitudes}

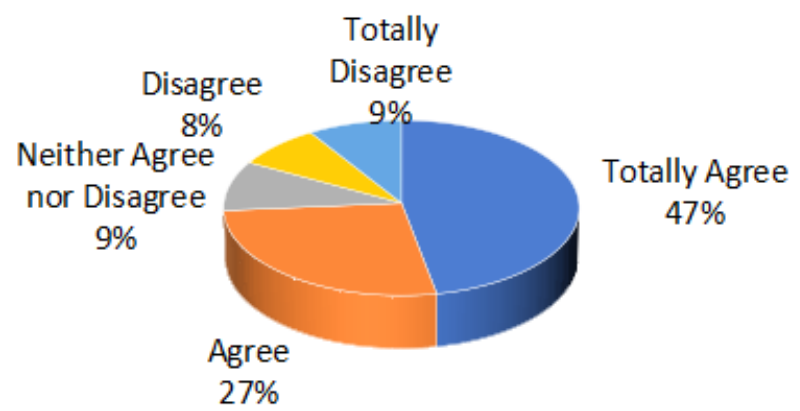

Figure 2. The Percentages of ESL Teachers' Attitudes

\section{DISCUSSION}

The descriptive statistics of the data analysis revealed that most of the respondents had positive attitude towards the Islamic education management policy of integrating Islamic values into their ESL classrooms. A total number of $47 \%$ of the respondents totally agreed and the other $26.26 \%$ agreed on the statements given on the questionnaire.

According to Issan et al. (2011), basically, teachers' teaching performances are influenced by their attitudes and commitments toward their professions, roles and duties. High percentage of positive attitudes found in this study could be interpreted that these 
ESL teachers were committed and responsible to respond to the policy of the school on integrating Islamic values into their classrooms. Some of the research studies claimed teachers' attitudes and their professional teaching and learning process were also conducted by Corina \& Valerica (2012), Ahmad et al. (2013) \& Andronache et al. (2014).

These findings were in line with the arguments of Madkur \& Albantani (2017) who said that putting Islam in all lessons was essential since, as Moslems, teachers are also responsible to preserve Islamic values through the activities conducted in their classes. Besides, Zaitun \& Wardani (2018) further added that learning of a foreign language with all its culture given along with Islamic learning will make the students not only be good at the language learned but also be able to select and choose which cultures are appropriate with Islamic values and which are not. Thus, at this stage, the positive attitudes shown by ESL teachers as the subjects of this research study revealed that they support school management policy in implementing integrated Islamic education into ESL classrooms. Veugelers \& Vedder (2003) described that in this type of integrated approach, both stimulating certain values and teaching language skills at the same time will promote better communication on those values.

\section{CONCLUSION}

This study concluded that ESL teachers' attitudes toward their schools management policy on integrating Islamic values into teachings were positives. It was resulted from the descriptive statistics which showed: a total number of $47 \%$ of the respondents' responses totally agreed, $26.63 \%$ agreed, $9.25 \%$ were neutral (neither agree nor disagree), $8.12 \%$ disagreed, and $9 \%$ totally disagreed.

This study was limited to discuss ESL teachers' attitudes toward Islamic school management which implemented the integration of Islamic values into their English classrooms. Total numbers of the participants as respondents were only 32 persons from several Islamic schools which mean only around 5\% out of around 630 Islamic schools involved in this study. It is strongly suggested for further research that will discuss similar topic to involve bigger respondents with deeper analysis and broader discussion by involving students and the policy makers of the schools.

\section{ACKNOWLEDGMENTS}

The writers are proposing their high appreciation to all ESL teachers involved as the respondents to this research study for their valuable time to voluntarily participate in accomplishing the questionnaire.

\section{REFERENCES}

Ahmad, I., Said, H., Zeb, A., Sihatullah, \& Rehman, K. (2013). Effects of professional attitude of teachers on their teaching performance: Case of government secondary school teachers in Malakand region, Khyber Pakhtunkhwa, Pakistan. Journal of Educational and Social Research, 3(1), 25-31.

Ali, S., Kazemian, B., \& Mahar, I. (2015). The importance of culture in second and foreign language learning. Dinamika Ilmu, 15(1), 1-10.

Andronache, D., Bocos, M., Bocos, V., \& Macri, C. (2014). Attitude towards teaching profession. Procedia - Social and Behavioral Sciences, 142, 628-632.

Aree, S., \& Rahman, S. M. A. (2016). Integrated Islamic Education in Southern Thailand and Nothern Malaysia: Reforms and challenges. Journal of Human Rights and Peace Studies, 2(2), 75-106. 
Awang, F. H. (2016). The significant of model school in pluralistic society of the three southern border provinces of Thailand. SHS Web of Conferences, 23, 1-11.

Brooks, M. C. (2014). School principals in Southern Thailand: Exploring trust with community leaders during conflict. Educational Management Administration and Leadership, 43(2), 232-252.

Brown, H. D. (1994). Principles of language learning and teaching (2nd. ed.). New Jersey: Prentice-Hall Inc.

Byrnes, D., \& Kiger, G. (1994). Language Attitudes of Teachers Scale (LATS). Educational and Psychological Measurement, 54, 227-231.

Cahyo, S. D., Muslim, M. R. U., Rahman, A. N., \& Pratolo, B. W. (2019). Needs analysis of Islamic-based English reading material for the Muhamadiyah Junior High School. International Journal of Evaluation and Research in Education (IJERE), 8(2), 286292.

Check, J., \& Schutt, R. K. (2012). Research methods in education. CA: Sage Publications.

Corina, B. C., \& Valerica, A. (2012). Teachers' perceptions and attitudes towards professional activity. Procedia Social and Behavioral Sciences, 51, 167-171.

Dixon, L. Q., Liew, J., Daraghmeh, A., \& Smith, D. (2016). Pre-service teacher attitudes toward english language learners. NABE Journal of Research and Practice, 7(1), 75105.

Ekowijayanto, M. (2020). The integration of Islamic values in implementing of learning english Islamic Education students perspective. Eternal, 6(1), 18-30.

Gursoy, E. (2013). Prospective ELT teachers attitudes toward the English Language in an EFL context. Journal of International and Education Research, 9(1), 107-113.

Issan, S. A. Y., Al-Nabhani, H. Z., Kazem, A. M., \& Al-Ani, W. T. (2011). Omani teachers' attitudes towards teaching as a profession. Indian Journal of Psychology and Education (IJPE), 1(1), 25-40.

Kaewsom, C. (2017). Education perspective evaluating service sector's strategies of the thai government in the deep south of thailand. JICSA, 6(1), 150-174.

Madkur, A., \& Albantani, A. (2017). Instilling Islamic values in foreign language teaching: An Indonesian context. Advances in Social Science, Education, and Humanities Research, 3rd International Conferences on Education in Muslim Society, 115, 97103.

Maryrose, O., \& Kingsley, N. (2018). Influence of teachers' attitude towards teaching profession on under-graduate non education students perception of teacher education. International Journal of Academic Research in Progressive Education and Development, 7(4), $67-79$.

Munastiwi, \& Marfuah. (2019). Islamic Education in Indonesia and Malaysia: comparison of Islamic Education learning management implementation. Jurnal Pendidikan Islam, $8(1), 1-26$.

Nitjarunkul, K., Sungtong, E., \& Placier, P. (2014). Challenges of educators in the context of education reform and unrest: A study of southern border provinces in Thailand. Asian Social Science, 10(18), $232-239$.

Saygi, C. (2010). Attitude scale development study in relation to music teaching course. Procedia Social and Behavioral Sciences, 2, 5451 - 5457.

Sener, S. (2015). Examining trainee teachers' attitudes toward teaching professions: Çanakkale Onsekiz Mart University case. Procedia Social and Behavioral Sciences, 199, 571-580.

Suryapermana, N. (2017). Management of Islamic Education at Islamic High School 
(Madrasah Aliyah): A study implementation of Islamic Education at Islamic High School of district Pandeglang. International Journal of Home Science, 3(1), 97-107.

Veugelers, W., \& Vedder, P. (2003). Values in teaching. Teachers and Teaching: Theory and Practice, 9(4), 377-389.

Wibowo, \& Utomo. (2018). Islamic Educational management for seventh grade students at SMPN 1 Wonosegoro. Humaniora, 9(3), 283 - 290.

Yukhong, C., Phuwanatwichit, T., Mangkhang, C., \& Sarobol, A. (2019). Socialization concepts and educational management development to create Muslim citizenship through private Islamic Schools in the southern border provinces of Thailand. International Journal of Islamic Thought, 15, 27 - 34.

Zain, K. M. (2018). Indonesian student-teachers' anxiety during their teaching practice in Southern Thailand. Kediri: IAIN Kediri.

Zaitun, \& Wardani, S. K. (2018). Islamic values in the context of english teaching and learning. English Language in Focus (ELIF), 1(1), 71-80. 